\title{
TRANSFORMATION STRATEGIES TOWARDS SUSTAINABLE CITIES SUSTAINABLE TRANSPORT STRATEGY IN KARBALA CITY
}

\author{
Shaimaa M. Hamza and Areej M. Abdulwahab \\ Dept. of Architectural, College of Engineering, University of AL-Mustansiriyah-Iraq
}

\begin{abstract}
Transportation is the most sector vitality in the city, and represents more sectors polluting, as it represents the ratio of pollution resulting from it by more than $65 \%$ of the total pollution in the city, and has negative effects on human health and community and other organisms, as well as their impact on the degradation, distortion and extinction urban interfaces especially heritage and archaeological buildings.

Sustainable transport is one of transition strategies towards sustainable cities that adopt modern trends such as Smart Growth and New Urbanism etc., which aims to provide:

- Providing quality of life for urban environment and free of polluting emissions.

- Providing suitable transportation modes, and taking into account the social, environmental, economic and physical dimensions of society.

- Sustainable transport gives priority to use of non-motorized transport modes (pedestrians, cyclists) in mobility as well as public transport (metro, tram, and bus etc.).

The search study of Mexico City experience, which adoption of sustainable transport to solve the pollution problem in the city by applying the policies most important to increase the number of lanes metro and public transport buses, and replacement of transport modes by other non-polluting and accommodate larger numbers of passengers and other policies, where application of these policies to improve the city's environment by providing and improving public transport, reduce number of private cars, and encourage transport modes is automated.

Suggested search sustainable transport adoption in Karbala city to importance of religious and historical city and prepare a set of proposals to reduce pollution in the city and organize and coordinate proposals plan and a design. the most important proposals are: city center proposals by emphasizing pedestrian traffic and use of public transport in transfer of visitors to city center and use of intelligent transport. As well as public transport proposals to establish a special public transport pathways inside residential neighborhoods.
\end{abstract}

KEYWORDS: SUSTAINABLE TRANSPORTATION, STRATEGY, KARBALA CITY, SUSTAINABLE CITY.

\section{Reasarch Problem}

Cities suffer from problems of pollution, especially from transport unsustainable modes and which is one of the most important pollutants in city and make it low life quality and negative impact on community health and building in city.

\section{Research Aim}

Adoption of sustainable transport strategy in city as one of sustainable cities strategy that achieved by applying multiple policies to consider sustainability dimensions of environmental, economic and social.

\section{Research Hypothesis}

Strategic shift towards sustainable cities achieved through applying a sustainable transport strategy in city as one of sustainable strategies that consider sustainability dimensions.

\section{INTRODUTION}

Cities suffer from the output of the modes of transportation of fossil fuels depends which produces an emission with negative impacts on urban environment and make non-sustainable urban pollution problem. Trends begun planning and design in modern cities such as smart growth, new urbanism to make cities sustainable and better quality of life, and most important at their strategies on sustainable transport as an alternative to the traditional transport in city.

Karbala city of most important holy cities in Iraq, the city suffers from pollution by transportation modes, it has been updated master 
plan and set a new transport plan adopted sustainable transport by providing pedestrian paths and adoption of public transport in movement mainly.

\section{1-1 Transportation In City}

Considered transport sector of most important sectors of city, as it aims to meet needs of community and lends dynamics of life in city, and to ensure comfort and safety for users, but it has a negative impacts on urban environment, especially road transport, which is main source of pollution of air-city, which contributes $70 \%$ from monoxide emissions of carbon $\mathrm{CO}$ which is considered most toxicity polluting gases due to length of remaining in air poisonous and its impact on human health, as well as dangers of health breaches of lead compounds resulting from use of leaded gasoline, a compounds leads to of which poisoning and influence health problems nervous system, as World Bank estimates that transport sector in major cities is a source of a third of total greenhouse gas emissions or more (Rasheeda, 2015, p. 115)

Defines transport is movement of people, goods, facilities and modes a system to do so (Qaded, 2009, p. 7). And proven studies impact of transport on human life, figure 1 shows extent of this influence and challenges and factors related to transportation of benefits and consequences as well as relationship between them.

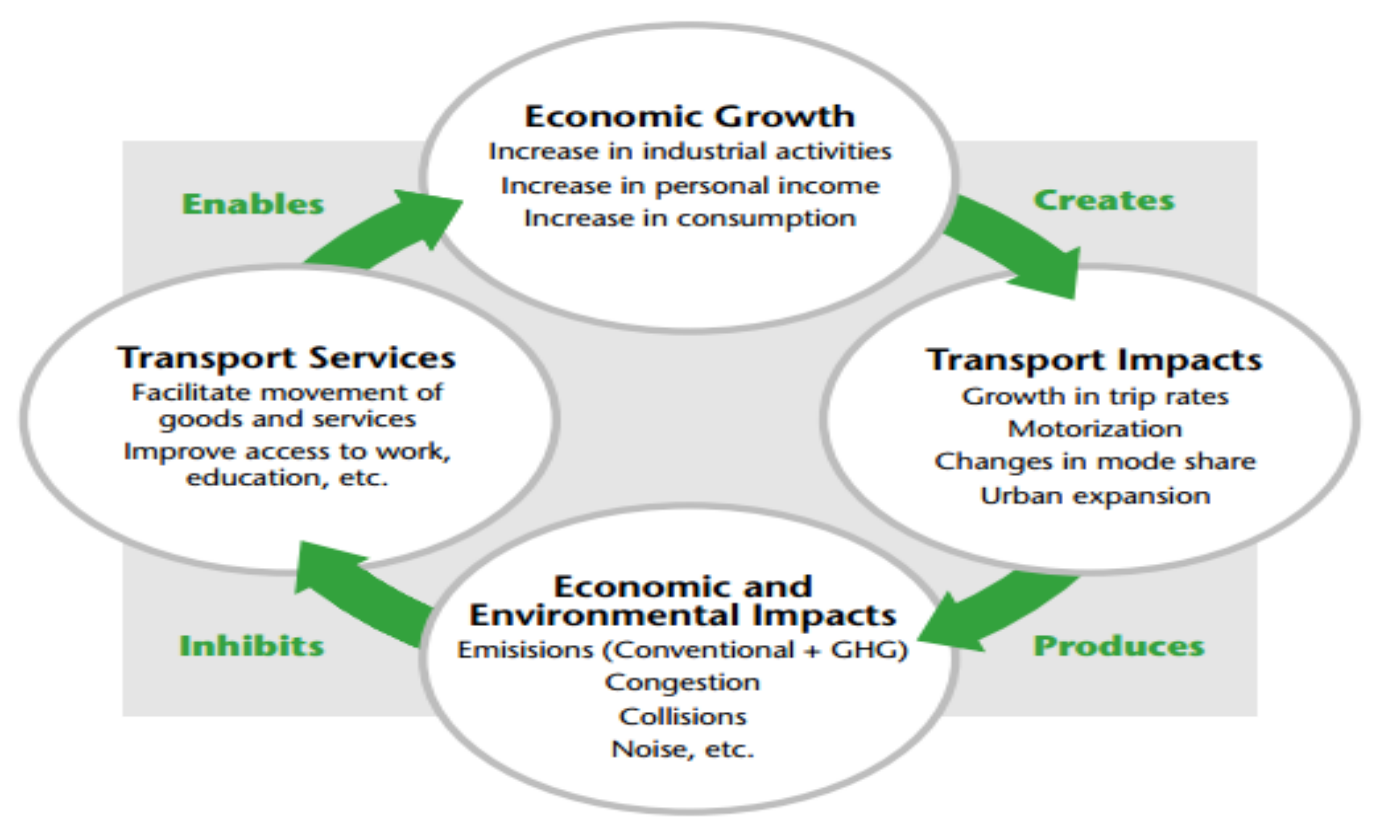

Fig (1): Effects of Transport in City (World business council for sustainable development, 2004, p. 13)

Shows figure above importance of transport services lifeline vital to economic development cycle, transportation allows a lot of large benefit for all sectors as well as operational capabilities offered by, as it provided the transportation sector 872 thousand a chance to work in United Kingdom, and 10.3 million jobs in America, and 7 million jobs in EU (World business council for sustainable development, 2004, p. 14). Pays transportation wheel of economic development allows the movement of human resources and material to long distances, and providing greater opportunities for workers to move between employment and housing without need for additional costs and thus increase economic activity and household incomes and increasing consumption and expansion of urban green land account and therefore their impact on environment by increasing gas emissions resulting from transport and affecting public health and environment in city and that leads to problems of 
environmental universal, and more than $95 \%$ of user in transport sector fuel of petroleum and to emissions in incidence levels of global greenhouse gases, most notably carbon dioxide (United Nations, 2001, p. 5). Growth of transport sector coincides with population and economic growth increase, lead it to increase vehicles and traffic problems in city and result in to increase pollutant emissions environment causing global warming.

\section{1-2 Sources Of Pollution Environmental Resulting From Urban Transport}

Motor vehicles of most important modes of necessary transportation, which works to secure human requirements, and this is reflected in increasing number of cars in world today, as statistics indicate that number of cars in world were not more than 20 million vehicles in 1918 and number increased to 95 Million in 1955 and reached 634 million cars in 1995 and jumped number to rise to 700 million units in 2000 to 750 million in 2005 to one billion cars in 2010. In the study in Germany expects number of cars around world, it is rising in 2015 to 1.124 billion cars, an increase of $20 \%$. It is known that human needs of the estimated amount of fresh air exceeds that of consumed water and food per day, so that amount of up to about 15 tons of air liters per day, which weighs about 16 kilograms, according to global data for effects of pollution sources, densely populated city of crowded modes of transportation downtown is a transport sector source of enormous amount of existing in air polluting gases rate of up to about 60 or more, so modes of transportation is largest in contamination of atmosphere thus overall climate pollution (Fig. 2).

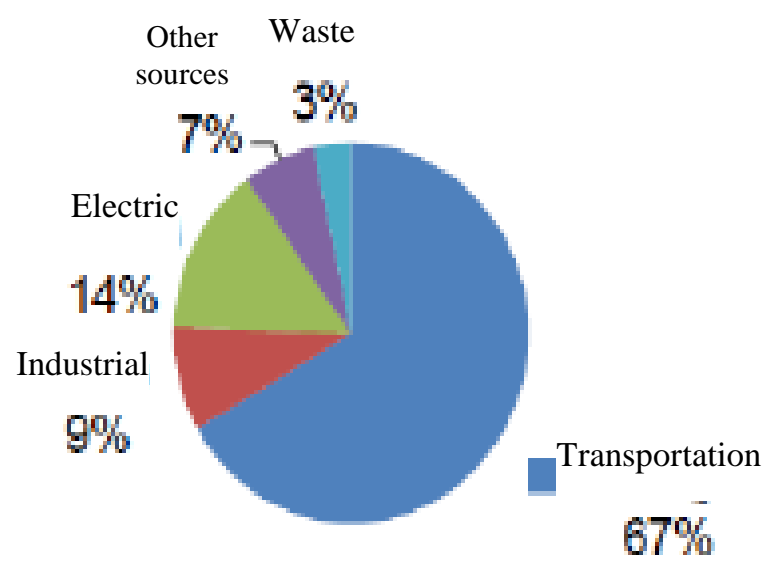

Fig. (2): Percentages of City Pollution Sources (Al Ameen, 2015, p. 2)

Shown in Fig. (2) transport sector is biggest polluter of city's air and represent $67 \%$ of the total pollution in city, while $33 \%$ of pollution in city, causing by industry, electricity, waste and other residential sources.

Scientific research carried out by many of specialized scientific institutions confirm that chemical compounds that are included in the composition of waste gases from transport modes it up to 200 compounds is gas carbon monoxide $\mathrm{CO}$ most dangerous and most toxic, followed by $\mathrm{NO}_{\mathrm{x}}$ and sulfur $\mathrm{SO}_{2} \mathrm{NO}_{\mathrm{x}} \mathrm{HC}$ and other pollutants.
Scientific studies in the United States and European countries have indicated that vehicles of various types contribute rate of $60-80 \%$ of oxides of carbon in atmosphere, as these studies confirm that carbon dioxide $\mathrm{CO}_{2}$ accounts for $21 \%$ of total mounting of process gases Combustion of hydrocarbons. (Al Ameen, 2015, p. 4)

Liquid fuels are one of liquid hydrocarbon compounds, where it works with internal combustion engines used in transportation and various transportation on use of liquid fuels such as gasoline and diesel, to produce necessary 
energy and convert it into kinetic energy for operation of vehicles, it has found that amount of air needed to burn $1 \mathrm{~kg}$ of fuel equal to $15 \mathrm{~kg}$ of weight, but in terms of size, combustion of one liter of fuel he has 9 tons' liter of air. And be perfect combustion process if it leads to a complete combustion of fuel, and in this case, will result in two articles: $\mathrm{Co}_{2}$ and $\mathrm{H}_{2} \mathrm{O}$ these two substances are toxic, although carbon dioxide is an environmentally friendly gaseous gas and contributes to global warming. In the case of incomplete combustion, that leads to emission of other pollutants more dangerous as such $\mathrm{CO}$ poison, through scientific research and previous studies on environmental pollution, several pollutants have been identified, which are major and are produced by the combustion of hydrocarbon fuel, both gasoline and diesel are: ${ }^{\mathrm{Al}}$ Ameen, 2015, p. 3): $\mathrm{CO}, \mathrm{CO}_{2}, \mathrm{NOx}, \mathrm{SO}_{2}, \mathrm{HC}, \mathrm{Pb}$, soot.

\section{1-3 Negative Effects Of Transport On City}

for transport sector, negative effects on city, including environmental, economic and social It is through knowledge of the negative effects of traditional transport in city and to compare transport Sustainable, we find following:

1. Power Consumption: transport sector needs worth one-third of the total energy consumption, as road transport requires about $80 \%$ of that value, in India, has compared the energy consumed when using bicycles, the energy consumed per mile using patterns mass transit increase of 2 to 2.5fold increase by 3 to 6 -fold when using the rest of the motor patterns. As the means of transport without engines consume $1 / 9$, which consumes transportation engines, since turning $51 \%$ of the mass transit users to use bicycles into urban ranges between $0.25-2 \mathrm{mi}$ reduces fuel consumption between 75-150 million liters of gasoline annually, and that shifted $10 \%$ of private car users to The use of bicycles in the same urban space reduces about 3 million liters of gasoline per year, and this means excessive energy use Limited areas due to the use of automated transport ${ }^{\text {(Rajat, }}$ 2011, p. 1341)

2. Gas Emissions: Government studies movements of people confirmed in United States in early nineties that car personal responsible for $20 \%$ of $\mathrm{CO}_{2}$ emissions and $45 \%$ of $\mathrm{CO}$ and $16 \%$ of gas $\mathrm{NO}_{\mathrm{x}}$ and about $25 \%$ of VOCs emissions, about 6755.8 million tons of $\mathrm{CO}_{2}$ emissions in $2010^{\text {(IEA STATISTICS, 2012, p. 69) }}$, or about $22.31 \%$ of the world cause in transport sector, $70 \%$ of the causes of air pollution is due to emissions from transportation in Bangkok city, either at level of suspended particulate ranging between $200-400 \%$ as gas ratio dioxide higher than the $50 \%$ of Measures of World Health Organization (WHO) and so throughout the 97 days a year. in Mexico, although car personal ratio represents only $15 \%$ of automated modes of transport, cause $63 \%$ of total emissions and $90 \%$ of dioxide emissions, while these studies have proved effectiveness of transition or at least improve structural base to accommodate non-motorized transport patterns and walking, reduction and reduction of Gas emissions and thus reduction of social costs.

3. Land Use: Light Rail Transit and pedestrians require less space than those required by bicycles, while other transport modes require more space than those required by bicycle movements, the required area of the road to one mobile using different patterns are as follows: $120 \mathrm{~m}^{2} \mathrm{car}, 12 \mathrm{~m}^{2}$ bus, $7 \mathrm{~m}^{2}$ for railways, $9 \mathrm{~m}^{2}$ for bicycles, $2 \mathrm{~m}^{2}$ for walking and $1.5 \mathrm{~m}^{2}$ for air transportation modes (teleferic). This shows that walking or using bicycles is the most effective mode of movement in traffic congestion. (Rajat, 2011, p. 1342)

4. Social Costs: a comparison of costs between various modes of transport patterns were studied based on many of a cost of accidents factors, parking, congestion, pollution air and noise, and energy consumption, and effects of land use and others. in a comparison of costs between various modes of transport patterns found that car cost used 27-times from its use of bike, and 134-times if the movement of walking, in while it can provide $44 \%$ of total cost use car if they were to switch to use of a variety of modes of transport (Multi Model) including walking and cycling, as the $4 / 3$ cost forward to modes of transport used and $4 / 1$ forward to public interest (for the benefit of society) this also pay reduced transportation costs for benefit of poor of society, specialization of 5-20\% of incoming monthly for their needs in Mobility. (Rajat, 2011, p. 1342)

5. Costs of Use and Congestion: estimated private employment expenses cars than double to ten times the expenses of use of bicycles. In different situations for traffic, considered moving walk or bike easier much of the mobility transportation other. cost of congestion in 
America of 100-300 billion dollars a year. the traffic congestion cost resulting from reduction in speed and loss of time was measured at about 1.4 billion dollars a year in Bangkok. However, cost of individual in a loss of time in been calculated on basis of 44 working days, including equivalent of $10 \%$ increase GDP of Thailand and 244 working days a year in city of Pune in Indian. ${ }^{\text {(Rajat, }}$ 2011, p. 1343)

6. Costs of Traffic Accidents: cost of influencing events in lives of individuals, such as fatal accidents, or that lead to permanent disability, and others up to 363 billion dollars a year, while navigating through transfer of non-motorized virtually no where accidents, studies have estimated social costs for use of roads in America between 60-860 billion US dollars annually, according to World Bank report (Strategies for Urban Transport) traffic accidents can be reduced significantly if they are to improve the rules for non-motorized transport, configuration of good roads, and effective management of transport policy . (Rajat, 2011, p. 1344)

\section{Distance Traveled and Time and Number of}

Trip: used modes of non-motorized transport in cutting short spaces they have periods exploit longest and number of trips more than rest of media, has a British study indicated that walk represents $2.8 \%$ of total distance kilo metric severed in trips, and $18 \%$ of time period for those trips, $25 \%$ of total trips, and data indicate that he had an international studies at the metropolitan level, solve each additional mile trips walk or use bicycles represent its value 7 miles from the flights using cars. ${ }^{\text {(Rajat, 2011, p. 1344) }}$

8. Ability to Absorb Movement: in a study to measure ability to accommodate passenger's own patterns of railways and public transport are between 4000 - 8000 passengers, will be about 3,500 to walk, and 1,500 for bicycles, while 100400 passengers for patterns Automatic transport such as the motorcycle and car personal among the movement of traffic urban. (Rajat, 2011, p. 1341)

9. Infrastructure Costs: investment required for provision of infrastructure based on space required to achieve movement for vehicles and attitude. Costs arising from configuration infrastructure to run some giant patterns (subway, urban railway and others) considered investments which lead to lower costs for future transportation services, while considered dedicated to exploitation of other patterns of costs relatively low if used it will produce costs of future is not estimated by the user for that style, but all who surround and remain sustainable modes (Bicycles and walking) less cost of patterns. (Rajat, 2011, p. 1341)

10. Necessary Preparations for Different Styles and Materials: found to be necessary for vehicles material much higher than even collects materials in that bikes need to be about $30 \mathrm{~kg} /$ person, the preparations required for vehicles varies from 4248 times to collect materials, bicycles Similarly ranging the requirement of 7-22 times ${ }^{\text {(Rajat, 2011, }}$. ${ }^{1341)}$, preparations that are manufactured subway, are much larger crowds Which it is estimated to take advantage of the train per flight, and this applies to rest of patterns alike.

\section{2-1 Sustainable Transport Concepte}

It refers to any method or practice or activity related to transport in field with a positive impact on environment and includes transportation is to, walking, cycling, Transit Oriented Development (TOD), Green Vehicles, Car Sharing, building or protecting systems efficient transport in fuel consumption in urban areas, save space and promote healthy lifestyles and create vibrant communities. (Jeon, 2005, p. 31)

This can be achieved sustainable transport to find ways to move people, goods and information less impact on environment, economy and society, and these methods represented some options, including (Meyer, 2004, p. 7):

- Modes of transport that use energy more efficiently, such as walking or cycling and public transport. Improve efficiency of use of cars such as use of more-efficient fuel consumption, driving more efficient vehicles and car assembly.

- Use of cleaner fuels and technologies.

- Use of telecommunications to reduce physical travel, or instead of, such as remote working or shopping from a distance.

- Cities are combining planning and nearly people and their needs and make cities more vibrant and viable to walk in them.

- Policies that allow and promote development of these options.

Canadian Union of sustainable transport defined according to achieve three dimensions of sustainability as follows (Amekudzi \& Jeon, 2005, p. 31).

1. Environmental Dimension: is reduction of emissions and waste (by air, soil and water pollution) within any urban area and works within 
capacity of environment in this region to accommodate the transportation infrastructure projects without degradation of environment through recycling, energy-saving vehicles from renewable energy sources or inexhaustible source in long term (such as solar energy), and recycling of natural resources used in automotive and infrastructure (such as iron and plastic).

2. Social Dimension: is to provide equal access for people and goods opportunities, for this generation and future generations, and to promote human health, and to assist in highest level of quality of life support compatible with available wealth, and facilitate urban development at a human level, and reduction of leak noise made by vehicles communities in less than acceptable levels, and make life safe for people and their property.

3. Economic Dimension: transport affordable in every generation; designed transport systems and working to maximize economic efficiency, help support a strong economy, and be a vibrant, diverse.
So, the sustainable transport system is defined as a system that provides effective access to goods and services for all urban residents, does not harm the environment, preserves the cultural and urban heritage for present generation, and does not endanger the chances of future generations to reach a level of prosperity current generations.

\section{2-2 Sustainable Transport Goals}

Need for a structured planning among various sectors and groups and the US comes as a result of overlapping of complex between nature and human activities, sustainability is working on expanding goals and impacts and options taken into account in planning process to accommodate this overlap, and this helps to emphasize to include individual decisions short-term into longterm strategic objectives ${ }^{\text {(Dobranskyte and others, 2007, p. 14). }}$

It can be divided targets sustainable transport, according to dimensions of sustainability to general and detailed goals with development of detailed indicators for each goal, as follows (Table $1)$ :

Table (1): Sustainable Transport Objectives, General, Detailed and Indicators according to Sustainability Dimensions (Litman, 2013, p. 5.)

\begin{tabular}{|c|c|c|}
\hline General objectives & Objectives detailed & Indicators \\
\hline \multicolumn{3}{|l|}{ 1. Economic } \\
\hline $\begin{array}{l}\text { Economic productivity } \\
\text { increase }\end{array}$ & $\begin{array}{l}\text { - Improve efficiency of transport system. } \\
\text { - Integration of transport system. } \\
\text { - To maximize ease of access. } \\
\text { - Improve efficiency of accessibility and } \\
\text { incentives }\end{array}$ & $\begin{array}{l}\text { - Per capita GDP is linked to transport sector. } \\
\text { - Part of allocated budgets for transport. } \\
\text { - Delaying congestion for everyone. } \\
\text { - Efficiency of pricing (roads, parking, insurance, fuel, etc.). } \\
\text { - Efficiency of identifying priorities for facilities and utilities. }\end{array}$ \\
\hline Economic development & - Development of economy and business. & $\begin{array}{l}\text { - Access to education and employment opportunities. } \\
\text { - Support for local industries. }\end{array}$ \\
\hline $\begin{array}{l}\text { Increasing energy } \\
\text { efficiency }\end{array}$ & - Reduce cost of energy. & $\begin{array}{l}\text { - Energy consumption per capita in transport sector } \\
\text { - Per capita use of imported fuel. }\end{array}$ \\
\hline Achieving reasonable costs & $\begin{array}{l}\text { - Can carry entire population access to basic } \\
\text { services costs (core) activities }\end{array}$ & $\begin{array}{l}\text { - Availability and quality of media reasonable transportation } \\
\text { costs (hiking, biking, ride sharing and public transport). } \\
\text { - Part of low-income households that spend more than } 20 \% \\
\text { of budgets in transportation. }\end{array}$ \\
\hline $\begin{array}{l}\text { Increase the operational } \\
\text { efficiency of the transfer }\end{array}$ & $\begin{array}{l}\text { - To maximize the efficiency of operations } \\
\text { and asset management. }\end{array}$ & $\begin{array}{l}\text { - Performance audit results. } \\
\text { - Service module costs compared with their peers. } \\
\text {-Quality of service. }\end{array}$ \\
\hline \multicolumn{3}{|l|}{ 2. Social } \\
\hline Achieving equity, justice & $\begin{array}{l}\text { To achieve transport system } \\
\text { accommodates all users, including those with } \\
\text { disabilities, and Low-income, and other } \\
\text { restrictions. }\end{array}$ & $\begin{array}{l}\text { - Diversity of transportation system. } \\
\text { - Part of points of access of persons with disabilities and } \\
\text { limited income. }\end{array}$ \\
\hline $\begin{array}{l}\text { Achieve safety, and the } \\
\text { safety and health }\end{array}$ & $\begin{array}{l}\text { - Reduce risk of accidents and attacks, and } \\
\text { support for fitness. }\end{array}$ & $\begin{array}{l}\text { - Rate of road traffic injuries (injury and death) for each } \\
\text { individual. }\end{array}$ \\
\hline
\end{tabular}




\begin{tabular}{|c|c|c|}
\hline & & $\begin{array}{l}\text { - Rate of abuse of passengers (crime). } \\
\text { - Human exposure to harmful pollutants. } \\
\text { - Part of the travel by walking and cycling. }\end{array}$ \\
\hline Community Development & $\begin{array}{l}\text { - Assistance in finding exclusive and } \\
\text { attractive communities. } \\
\text { - support for cohesion of local communities. }\end{array}$ & $\begin{array}{l}\text { - Mixed land use. } \\
\text { - Possibility of walking and the possibility of using bikes. } \\
\text { - Quality of road and street environments. }\end{array}$ \\
\hline $\begin{array}{l}\text { Protection of cultural } \\
\text { heritage }\end{array}$ & $\begin{array}{l}\text { - Protection of and respect for cultural } \\
\text { heritage. } \\
\text { - Support for cultural activities. }\end{array}$ & $\begin{array}{l}\text { - Conservation and cultural traditions. } \\
\text { - Response of traditional communities. }\end{array}$ \\
\hline \multicolumn{3}{|l|}{ 3. Environmental } \\
\hline $\begin{array}{l}\text { Maintaining stability of } \\
\text { climate }\end{array}$ & $\begin{array}{l}\text { - Reduction of greenhouse gas emissions. } \\
\text { - Mitigating the effects of climate change. }\end{array}$ & $\begin{array}{l}\text { Per capita emissions of greenhouse gases (CO2, CFCs, } \\
\mathrm{CH}_{4} \text {, etc.) }\end{array}$ \\
\hline Prevention of air pollution & $\begin{array}{l}\text { - Reduce air pollution emissions. } \\
\text {-Reduction of exposure to harmful pollutants. }\end{array}$ & $\begin{array}{l}\text { - Emissions per capita (PM, VOCs, NOx, CO, etc.) } \\
\text { - Air quality standards and management plans. }\end{array}$ \\
\hline Prevention of noise & - Reduce exposure to traffic noise & - Level of transport noise \\
\hline $\begin{array}{c}\text { Protection of water quality } \\
\text { and reduce damage } \\
\text { hydrological. }\end{array}$ & $\begin{array}{l}\text { - Reducing water pollution. } \\
\text { - Reduce the surface area paved }\end{array}$ & $\begin{array}{l}\text { - Fuel consumption per capita. } \\
\text { - Used oil leaks and storm water management. } \\
\text { - Per capita impregnable surface area. }\end{array}$ \\
\hline $\begin{array}{l}\text { Protection of biodiversity } \\
\text { and open areas }\end{array}$ & $\begin{array}{l}\text { - Reduce transport facilities in land use. } \\
\text { - Encourage more compact development. } \\
\text { - High-quality habitat protection. }\end{array}$ & $\begin{array}{l}\text { - Allocated to transport facilities for each individual territory. } \\
\text { - Support for development of smart growth. } \\
\text { - Policies to protect agricultural land of high-value habitats. }\end{array}$ \\
\hline \multicolumn{3}{|c|}{ 4. Good governance and planning } \\
\hline $\begin{array}{l}\text { Integrate, comprehensive } \\
\text { and urban planning }\end{array}$ & $\begin{array}{l}\text { - Select or clear definition of planning } \\
\text { process. } \\
\text { - Integrated and comprehensive analysis. } \\
\text { - Engage citizens strongly. } \\
\text { - Low-cost planning or Lease rent cost } \\
\text { planning (and are choosing most } \\
\text { advantageous solutions and funding). }\end{array}$ & $\begin{array}{l}\text { - A clear definition of overall objectives and detailed } \\
\text { indicators. } \\
\text { - Availability of planning documents and information. } \\
\text { - Part of population involved in planning decisions. } \\
\text { - Objectives and effects and options-based group or taken } \\
\text { into account. } \\
\text { - You could spend money on alternative modes of } \\
\text { transportation demand management if more beneficial } \\
\text { overall. }\end{array}$ \\
\hline
\end{tabular}

2-3 Strategies And Policies For Sustainable Transport Planning

1. Avoidance Strategy: Avoid non-essential travel and reduce flight distance. This strategy can be achieved through following policies (Shanghai Manual, 2009, p. 36):

- Official policy of integration between land use planning and transportation planning and institutional arrangements related to level of city operations.

- Achieve versatile medium to high-density development along the main corridors within cities, and to promote TOD when the introduction of new infrastructure for public transport.

- Establishment of policies, programs and projects that support information and communication technology (ICT).
2. Transformation Strategy (Shift): shift towards more sustainable modes. This strategy can be achieved through following policies ${ }^{\text {(Shanghai }}$ Manual, 2009, p. 36).

- Give priority to non-motorized modes of transport in major plans for transport in infrastructure investments.

- Improving public transport services.

- Reduce share of urban transport modes of special vehicles mechanism through transport demand management measures (Transportation Demand Management).

- Achieve significant shifts in modes more sustainable commuter and inter-city transportation of goods.

3. Optimization Strategy (Improve): improving transportation practices and technologies. This 
strategy can be achieved through following policies (Shanghai Manual, 2009, p. 37):

- Support work towards fuel technologies and most sustainable transport (use of electric cars, cars of renewable energies, hybrid technology and natural gas).

- Stimulate goals, plans, policies, standards and national economy in motor fuel consumption through adoption of appropriate incentives locally and that will help adoption and use of cleaner and more efficient fuel vehicles.

- Imposition of standards for the quality of fuel and exhaust emissions for all types of vehicles, including new vehicles in use, laid down by competent authorities responsible.

- Imposition of car testing and compliance systems, including registration of official vehicles and Inspection timely periodic maintenance of vehicles and systems according to the requirements laid down by party responsible.

- Achievement of improving efficiency of freight transport, including road, rail, through policies, programs and projects that technology shipping vehicles occur, implementation of the control and monitoring of fleet management systems, and support best logistics and supply chain management or supply.

- Adoption of intelligent transportation systems (ITS), such as electronic fare for journey and regulations of road user fees and transportation centers, control, and real-time information to the user, wherever warranted.

4. Protection Strategy (Protect): to protect people and environment and protect people considered a priority. This strategy can be achieved through following policies (Shanghai Manual, 2009, p. 37):

- Work to achieve the policy - reduction of mortality with respect to roads and railways, and safety of waterway and implementation of appropriate design of infrastructure of roads, speed control, and strategies to reduce traffic, licenses strict driving and vehicle registration and insurance requirements, and better care for after accidents, big cuts oriented accidents and injuries.
- Strengthen monitoring of health effects of transport and noise emissions, assess and evaluate economic impacts of air pollution and noise, and to develop mitigation strategies, especially assisting vulnerable groups of populations near high traffic concentrations.

- Imposition of national standards for air quality and noise, taking also into account the guidelines of World Health Organization, and programs for monitoring and reporting.

- Implementation of low carbon sustainable transport to reduce causes of global climate change and contribute to national energy security measures.

- Adoption of planning and design standards to achieve social justice in development and implementation of transport infrastructure projects.

- Encourage innovative mechanisms for financing transport infrastructure and sustainable operations through measures such as imposition of parking, and fuel prices and imposition of road use automated transfer fees at a specific time of day, and partnerships between public and private sectors, including consideration of carbon markets, whenever possible.

- To encourage widespread distribution of information and awareness in modes of sustainable transport for all levels of government and public through awareness and promotional campaigns, and provide timely reports to monitor indicators, and participatory processes.

- The development of institutions and funding dedicated to research to achieve sustainability of policies of transport, land use, including research and development on environmentally sustainable transport, and promotion of good governance through implementation of environmental assessment of strategic plans for transport and assessing environmental impact of projects.

The table (2) shows proposed policies for sustainable urban transport system and purpose and effects. 
Table (2): proposed policies for sustainable transport system and the purpose and effects

\begin{tabular}{|c|c|c|c|}
\hline & Policies & Purpose to & Effect \\
\hline 1 & $\begin{array}{l}\text { Change in form of urban and } \\
\text { land use patterns }\end{array}$ & $\begin{array}{l}\text { Highly centralized to avoid intensive } \\
\text { development of city center (CBD). }\end{array}$ & $\begin{array}{l}\text { (Urban effects) development of new urban areas and } \\
\text { regions of Parties to contribute to decentralization of } \\
\text { urban functions and create a dynamic balance } \\
\text { between work sites and residential areas. }\end{array}$ \\
\hline 2 & $\begin{array}{l}\text { Integration between land use } \\
\text { planning and transportation } \\
\text { planning }\end{array}$ & $\begin{array}{l}\text { Maximum efficiency of urban } \\
\text { transport system to overcome } \\
\text { obstacles and environmental } \\
\text { determinants and resources of city. }\end{array}$ & $\begin{array}{l}\text { (Economic, social and environmental impacts). (Easy } \\
\text { access), and change behavior of people in movement, } \\
\text { intensity of land use, and integration of transportation } \\
\text { planning with land use planning all this will maximize } \\
\text { efficient use of resources and options for transport to } \\
\text { enable a sustainable transport system. }\end{array}$ \\
\hline 3 & $\begin{array}{l}\text { Improving public transport } \\
\text { and transport-oriented } \\
\text { development }\end{array}$ & $\begin{array}{l}\text { To improve public transportation and } \\
\text { follow compact and mixed-use urban } \\
\text { communities' designs and reduce } \\
\text { excessive use of private cars. }\end{array}$ & $\begin{array}{l}\text { (Designs) to create integrated communities with public } \\
\text { transport as a focal point essential to encourage use of } \\
\text { public transport and reduce use of private cars. }\end{array}$ \\
\hline 4 & $\begin{array}{l}\text { Integration between agent's } \\
\text { transport (transport partners) }\end{array}$ & $\begin{array}{l}\text { To provide an integrated transport } \\
\text { system there is compatibility between } \\
\text { the road and rail-based public } \\
\text { transport. }\end{array}$ & $\begin{array}{l}\text { This will improve interaction between railway and road- } \\
\text { based public transport or distribution capacities and } \\
\text { passenger transport, and mitigation of endurance and } \\
\text { inconvenience passengers. }\end{array}$ \\
\hline 5 & $\begin{array}{l}\text { Transport fares low for } \\
\text { categories of low-income }\end{array}$ & $\begin{array}{l}\text { To provide justice for low-income } \\
\text { groups. }\end{array}$ & $\begin{array}{l}\text { This helps low-income subsidized to navigate } \\
\text { categories. }\end{array}$ \\
\hline 6 & $\begin{array}{l}\text { Maintenance and } \\
\text { implementation of laws and } \\
\text { policies of urban transport }\end{array}$ & $\begin{array}{l}\text { To develop a system of sustainable } \\
\text { transport implementation of laws and } \\
\text { policies of transport. }\end{array}$ & $\begin{array}{l}\text { This case will determine mode of transport, sources of } \\
\text { funding for transportation, and the principles of } \\
\text { transportation planning, transportation management } \\
\text { systems, transport-related issues. }\end{array}$ \\
\hline 7 & $\begin{array}{l}\text { Use of economic instruments } \\
\text { to restrict car use }\end{array}$ & $\begin{array}{l}\text { To curb car use and encourage use } \\
\text { of public transport. }\end{array}$ & $\begin{array}{l}\text { This reduces traffic congestion and will secure easy } \\
\text { access to all segments of society. }\end{array}$ \\
\hline 8 & $\begin{array}{l}\text { Transport network is } \\
\text { automated processing }\end{array}$ & $\begin{array}{l}\text { Encouraging means non-motorized } \\
\text { transport is one of most sustainable } \\
\text { transportation. }\end{array}$ & $\begin{array}{l}\text { It means non-motorized transport or movement is } \\
\text { automated is efficient use of energy, and transfer } \\
\text { mode environmentally friendly, which would enhance } \\
\text { mobility in urban areas and reduce output of transport } \\
\text { pollution. }\end{array}$ \\
\hline
\end{tabular}

\section{2-4 Sustainable Transport Planning Tools}


Planning for sustainable transport several different tools, including:

1- Control Demand for Transport: Studies show that transport demand management (TDM) can reduce vehicle trips by up to 30 or $40 \%$. It aims to encourage non-use of private vehicles and use of Transport characterized as most environmentally and healthy efficiency of public transport and transport non-automated (Victoria Transport Policy Institute, 2009, p. 8) and includes (TDM) set of tools are:

A. Planning Tools: planning reduces need to navigate through rounded population of events that need access to it (putting them close to places). Planning makes the implementation of transport infrastructure is enabled by easier and better. It is planning tools set up positions around cities to achieve two objectives:

- Easing traffic congestion in cities and encourage use of collective transport.

- Protect city environment from pollution (Mqlata, 2004, p. 50)

As well as determine stand inside cities by reducing special places in city center or stand up cost of using position (different costs depending on number of passengers, abolition of free, and charge a fee to stand). These policies lead to reduced traffic and trend towards public transport . Other planning tools, to encourage employers to programs, with institutions contributing to identify transportation patterns, it could affect factors that support use of car (such as displaying parking of worker's cars), and employers can help solve congestion problems affect working conditions (Times of work, place of work programs) that determine demand for transport and reduce mobility of individual private cars flying toward work and these programs include:
- Shared car program: official compilation of common car users.

- Reduction in number of parking spaces, to encourage use of alternatives to private cars.

- Encourage mass transit (to reduce cost of mobility, for example) and transportation is automated.

The real impact of these programs to change behaviors are socially and economically working to reduce transport cost and reducing environmental pollution caused by increasing number of cars.

B. Regulatory Tools: include International Standard-local (such as the determinants of emissions, and safety), traffic regulation (determinants of speed, parking lots, roads and the allocation of space).

Regulatory measures are used to reduce use of certain motor vehicles, affect types of vehicles used and standards that must be credited or required performance vehicles and organize ways.

Among regulatory tools, customizable roads by separating public transport private paths to avoid traffic congestion by identifying a section of public roads for their own use to ensure a certain accelerated and organize transportation without need for movement of more, divided into three groups (Bin Abdul Aziz, 2011, p. 24):

- customized tracks: Part of way through paint signs on street for passage of collective modes of transport, it can also be open to buses, taxis, ambulances, and other buses and others. The creation of such tract is only in areas where there is little traffic flow and not on an ongoing basis

- special path: where is allocated separately from rest of way or hallway is created on new flooring is similar to your path Tramway(Figure 3).

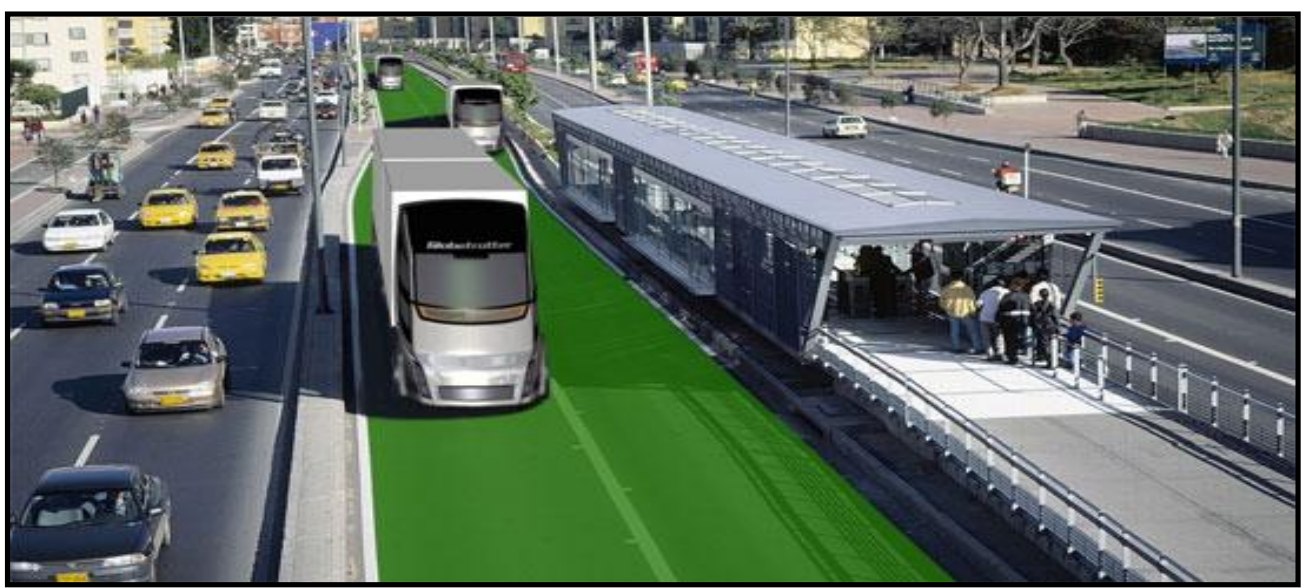


Fig. (3): Special Path for Public Transport

http://sustainablecitiescollective.com/global-site-plans-grid/1073276/sherbrooke-quebec-business-owners-footingbill-bike-infrastructure-up

- mixed roads allocation: where prohibit general traffic, regulatory standards are allocated only for pedestrians and modes of joint transportation that run specific speeds (given priority, except at level of pedestrian corridor), it increases the size of sidewalks to provide more space for pedestrians and be on same level with the road, this solution is often at the center of city at level of relatively short straps with small shifts or to perform a special service.

We can say that goal of roads allocation is to reduce congestion and improve quality of environment by reducing number of vehicles on roads, and then reduce fuel and emissions from automobile consumption, and increase number of passenger vehicles in a way that raises road infrastructure efficiency.

C. Economic Instruments: including tax or fuel surcharges, roads price, subsidies, purchase taxes, fees and levies, and emissions trading. You can clarify these fees and taxes through:

- Drawing funding: intended to finance road infrastructure or public transport.

- Regulatory fee: This fee is working to regulate traffic and improve movement through behavior of driver change (reduce individual transfers).

- Environmental fee: objective of this fee is to reduce environmental damage (such as pollution, noise ...) and uses this fee to improvement of infrastructure and network of public transport and reduce congestion and thus increase supply of alternative transport.

- Taxes: tax on fuel for example.

D. Information Tool: it includes public awareness, mobility management plans and marketing campaigns or organizations, cooperation agreements, and environmental regulations driving. Providing information in a manner easily accessible, it can increase awareness of alternatives modes of transport and lead to a shift by transport towards walking and bike, as will all things related to improving driving behavior and mobility leading to reduced fuel consumption.

E. Technological Tools: include improving fuel, clean technology, technology end of the tube and cleaner production (End-of-pipe Technology). When movement of vehicles or so-called automated necessary to move, technology becomes useful for reducing effects of carbon emissions, through development of clean fuel and improve efficiency of vehicles. All the tools you mentioned contribute to reducing carbon emissions (Victoria Transport Policy Institute, 2009, p. 18).

2- Mass Transit: Do not dispense cities for mass transit to move people to places of work or shopping and access to services, is associated with this type of transport and number of passengers commuting distances required for the ride. It is a mass transit via pathways of most important pillars of sustainable transport, it can contribute greatly to solving many of problems of urban transport.

Urban planning today considers mass transport policies, because completion of axes mass transit (either through special lanes or without them) often constitute opportunities for creation of many of economic and commercial projects and urban planning projects, especially on multi-modal transport stations, thereby contributing to mass transit development urban and spatial spread (Bin Abdul Aziz 2011, p. 28). Most important of these mass transit arguments are (Ashmawy, 2008, p. 56): subway (Metro), urban train (Tramway), electric bus (Trolleybus), bus (BRT), and train wired (Funicular).

Different modes of mass transit modes are optimal for reducing pollution, as contributing to the reduction of greenhouse gas emissions and reduce congestion. It should be pointed to need to improve mass transit (quantity and quality), by media more to preserve quality environment high transfer to reduce congestion and maintain quality of air service, as well as developing and accelerating infrastructure wild ways and stations and to ensure geographic coverage adequately ${ }^{\text {(Bin }}$ Abdul Aziz, 2011, p. 29)

3- Mobility is Automated: Walking and cycling may play important roles as complementary mass transit while providing convenience of individual mobility, and these forms is the mechanism to navigate called fresh patterns, have potential inherent to participate significantly share in 
transport if directed towns attention to pedestrian needs, cyclist's bikes (Bin Abdul Aziz, 2011, p. 35)

A. Walking: Natural way to move, since it requires no mechanical help, which is most prevalent in cities, especially way specific categories, namely: children, women, pensioners, persons not holding a driving license, but this kind of movement because of limited physical infrastructure and energy for different individuals (Victoria Transport Policy Institute, 2009, p. 33)

B. Bike: that use of bicycle is growing day after day, and is characterized by this kind of transport as a mode very economical transport does not occupy a large place of urban space, with a relative flexibility in movement, as well as being non-polluting at all for environment during use and it encourages activity physical for individuals (Bin Abdul Aziz, 2011, p. 36)

C. Car Joint: joint use of the car is one of most important alternative modes of transport, especially in areas characterized by poor public transport services, meaning to be several people in one car for purpose of diminishing number of cars on way to reducing individual mobility. This idea began in eighties in France, where public authorities have encouraged individuals and families to navigate group, and the goal is to increase efficiency of transport network to increase number of passengers in each car and reducing rate of transmission of individuals alone in the car. You can identify common forms of car:

- Own vehicle (Carpool): mostly used among family members.

- Small truck (Vanpool): show generally at institution, and rarely in individuals, and often uses this kind of movement of long-distance.

- Sharing Car: It is an institutional network (official) applied in France, its principle that a person gets on a car without having to buy one, which is intended for people who need to regularly car. As it is contracted with company to get the car at time and place that he wants person, and result will be fewer cars in terms of numbers and use them more (Victoria Transport Policy Institute, 2009, p. 43).

4- Technological Solutions to Problems of Transport in Long Term: assisted technology in development of transportation and increased pollution, but is now turning more and more to find appropriate solutions to reduce output of transportation pollution, transport infrastructure, for example, are:

A. Biofuel: consists of ethanol a vegetable source (peaks, for example), which is characterized by fact that $\mathrm{CO}_{2}$ released him balanced in part with $\mathrm{CO}_{2}$ in atmosphere posed by plants during their growth, as well as consumption of 1 liter of this fuel leads to reduced $75 \%$ of greenhouse gas emissions compared to consume same amount of fuel hydrocarbons. (Barakat 2010, p. 68)

B. Vehicles: development of electric cars powered by electric battery can be charged thereby reducing gas $\mathrm{CO}_{2}$, hybrid cars powered by fuel and battery at same time, as well as development of fuel cells (Fuel Cell), a promising cell applications and wide in future ${ }^{\text {(Barakat, 2010 p. 69) }}$.

C. Infrastructure Improvement: reducing pollution through improving infrastructure and facilitate flow of traffic, and be optimization using construction materials environmentally friendly, as well as use of methods of waste reduction, reuse and recycling, among others.

D. Intelligent Transport System (ITS): intended various modern technologies applied in transport in order to:

- Assist in driving and determining private sites use system (GPS).

- Management of traffic and facilitate flow of traffic flows to control light signals. For example, about the weather - traffic safety by sending information to road users Management (Barakat 0.2010, p. 70)

Technology is often used when it cannot use other policies and tools for sustainable transport is most important benefits of application of intelligent systems for transport is to increase efficiency of traffic management, reduce pollution, provide information, saving time and effort and save safety.

\section{3-1 Sustainable Transport In Mexico City}

Pollution in city level poses a threat to public health, since experts confirmed that spend a day in city, equivalent to consumption of 40 cigarettes a day, and geographical structure of the city is other lead to aggravation of situation as a result of there, Reduced oxygen level in air to extent of $2200 \mathrm{~m}$ above sea level leads to complete lack of combustion engines and fuel gas high proportion of $\mathrm{CO}$ with other molecules, as well as brightness of sun and high temperature exacerbates problem 
converts these gases and volatile molecules to heavy smog. It was necessary to shift towards sustainable transport in the city to meet these challenges, as results became clear to a large extent, while exceeded ozone international standards level (estimated at 0.1 molecule million) for 333 days in 1990, that number had dropped to only 180 days in 2009 of biggest challenges in Mexico city is to reduce use of private cars as a result of due to infrastructure motivating them (to stimulate car use and ownership), and improve standard of living of families as a result of increased economic and social development, and weakness of public transport services and lack of responsiveness to needs of users on quantitative

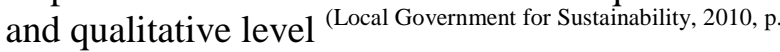
1).

Mexico City is largest urban agglomeration in North America, the economic, political and cultural capital of country, with a population of about 21 million people. Transfer is considered a vital factor in lives of Mexicans, millions commute to and from work an average of 2.5 hours a day, as it holds city about 28 thousand microbuses poses a threat to environment, while increasing the number of bikes, but culture of car ownership in the city made it navigate by bike a serious pattern of patterns urban transport (Local Government for Sustainability, 2010, p. 2)

\section{3-2 Sustainable Transport Policies In Mexico City}

Mexico City has adopted a policy of push and pull and create appropriate environment. Based government endeavors to achieve a more sustainable transport on following elements system (Local Government for Sustainability, 2010, p. 2-3)

1- Increase corridors for Metro and Buses, where scheme proposed increasing 12 line to the system Metro, which is largest system of underground in world, only feasibility study when you add this line, it provides flights to more than 367 thousand passengers per day during working days.

2- Increase three special passages bus for two of current transport channels, has achieved a bus metro system (Metro bus) (Figure 4) (special passages bus only) a resounding success since its adoption in 2005 an effective style in the city, as scheme proposed to replace micro-bus vehicles (Microbus) of old and polluting vehicles larger and more companionship environment.

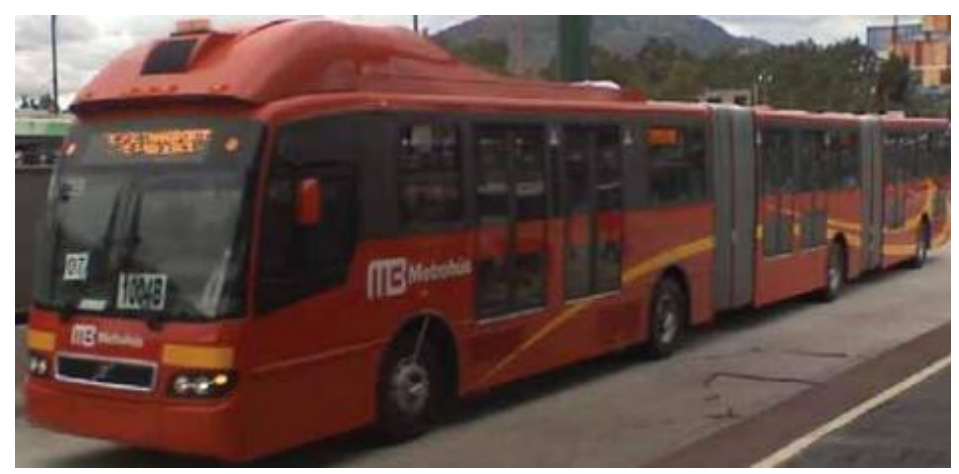

Fig. (4): Metro Bus in Mexico City

Local Government for Sustainability, 2010, p. 3

3- About $50 \%$ of private schools to Mexico City students enrolled in their schools through cars, causing $25 \%$ of congestion within the city to counter this problem, it was the integration of a compulsory transfer of pupil's program (PROTE) to reduce number of cars and encourage students to navigate walk or bike or use mass public transport.
4- Scheme is trying to pay more attention to patterns of movement is mechanism by creating necessary conditions for that, it has prepared a pedestrian requirement in vicinity and environs of historic center in 2010, with establishment of a special bike lanes under name of "pathways program is the mechanism," which contains a program educational called "ride your bike." 
5- On Sunday, preventing vehicle access to part of Avenue (Paseo de la Reforma) one of largest downtown streets, so as to customize broader picnic and activities of pedestrian and cycling entertainment field, and private transport scheme city Enter the shared bicycle system (Eco bike) in strategic areas in the city center, and began to work with this system in 2010, as it allows users to rent bikes for short periods and at affordable prices, and possibility of user traced to 85 stations in the city center. These stations are located near public transportation, which allows for transition between different modes of transport positions.

6- For Ways scheme, has been allocated a program works to reduce traffic congestion significantly through program "Do not drive today." The program aims to relieve congestion and improve air quality by blocking vehicular traffic for one day a week. It was identified on Saturday of each week.

7- Care plan to improve road infrastructure, as it has been amended some of the ways to solve 350 intersection in the city, as well as development of smart traffic signals along the main roads.

\section{3-3 Results And Implicants Of Sustainable Transport Application}

Results began to appear in all five areas of plan after 3 years from the planned application, and these effects are (Local Government for Sustainability, 2010, p. 4):

1- Improve Quality and Provision of Public Transport: Plays metro bus currently two lines different with a capacity estimated at 473 thousand passengers a day, $15 \%$ of them have switched from using personal car to public transport, and as a result of use of this pattern is level of carbon dioxide decreased by 8,000 tons per year, and extended bus system to serve $50 \mathrm{~km}$ as gallery of special Third fleet of buses in progress and is attached to system, and creation of five corridors in 2012, as well as establishment of line 12 of Metro, which began work there in 2008 has been establishment of 470 vehicle Micro bus formed many risks on environment and traffic safety 128 large buses using environmentally friendly fuel technology.

2- Reduce number of vehicles during traffic: Forced relocation program of the adoption of students, which prevents parents to accompany their children to school using their car in 2009 in some private educational institutions, and in a gradual arrived by 2010 to 21 involved in this program, the school, at beginning of application program faced many obstacles during its application for reasons of safety and cost.

3- Encourage Modes of Transport is Mechanism: Extension of private lines bicycles for $31 \mathrm{~km}$, as well as Sunday system that became known among citizens, which led to a change in behavior of mobile workers to organize him more than 4,000 users in first three months only, as much as number of transfers by bicycle about 50 thousand trips within the city using bicycles Eco Bike.

4- Roads Movement: led program "Do not drive today," which calls for non-use of car to reduce 960 tons of vehicle pollutants from hydrocarbon and dioxide and nitrogen oxides every Saturday, also led to a daily average reduction (except Sunday) cars on streets city to 342 thousand cars.

5- Encourage Most Respected for Pedestrians and Bicycles New Ways Culture: Traffic law for Mexico City updated in 2009 cared more to improve safety for pedestrians and bicycles conditions, as it relied on two main factors for success of sustainable transport to Mexico City scheme, namely: improving public transport system considering eco-efficiency of this system, and encouraging initiatives and programs calling for success of automated transport such as walking and bike patterns.

\section{4-1 Karbala City}

Karbala Governorate area is $652 \mathrm{~km}$, which accounted for $13 \%$ of the whole province. Estimated population of Karbala province 1013254 peoples in 2009, and amounted to $1,151,152$ people in $2014,2.58 \%$ growth rate, and estimated population of Karbala city 770762 peoples in 2009, with 878375 peoples in 2014 with a growth rate of $2.65 \%, 2.65 \%$ growth rate. (Ministry of Planning 2010, p. 10) and (Ministry of planning, 2014, p. 93)

The expected population for transportation plan in Karbala city is 2287275 peoples in 2030 . (Physical planning office, Karbala, field visit)

\section{4-2 Existing Transportation In Karbala City}

A. Public Transport: Implementation of many new roads planned in 1990 within foundation planned for Karbala city proposals, with internal and external transport network (which exploits transfer stations). Proportion of use of public 
transport by residents of the city $33 \%$, and lack of public transport to diversity of transportation.

B. Private Transport: a decrease in ownership of individuals for private cars rate within Karbala city, and it is unclear compensate for shortfall in ownership of individuals for private cars in good network transfer rate inadequate.

C. Pedestrians: Most of workers live near shops of their work, especially those who live in city center, they are moving on foot with poor current methods for pedestrians and failure to provide comfort and safety requirements. As well as movements in city that are made by bike, especially distances are relatively nearby. (Physical planning office, Karbala, field visit)

\section{4-3 Proposals Transport Plan In Karbala City The Proposed (1): Status of Transport to City Center}

City center area densely populated old houses and narrow streets and busy all year round visitors and increasingly nights combining religious and visits, so it is only used for pedestrians all year round, but rest of areas such as $\mathrm{Bab}$ Al Khan and Alapasian, streets introduce and implemented on a regular basis and where markets and movement of commercial serve residents of the city, she suggested plan to be open to vehicles but are restricted where they cannot accommodate vehicles in absolute terms, and are only for millions of visits pedestrians days (Map 1).

Map (1): Allocated to Pedestrians' Areas in The City Center

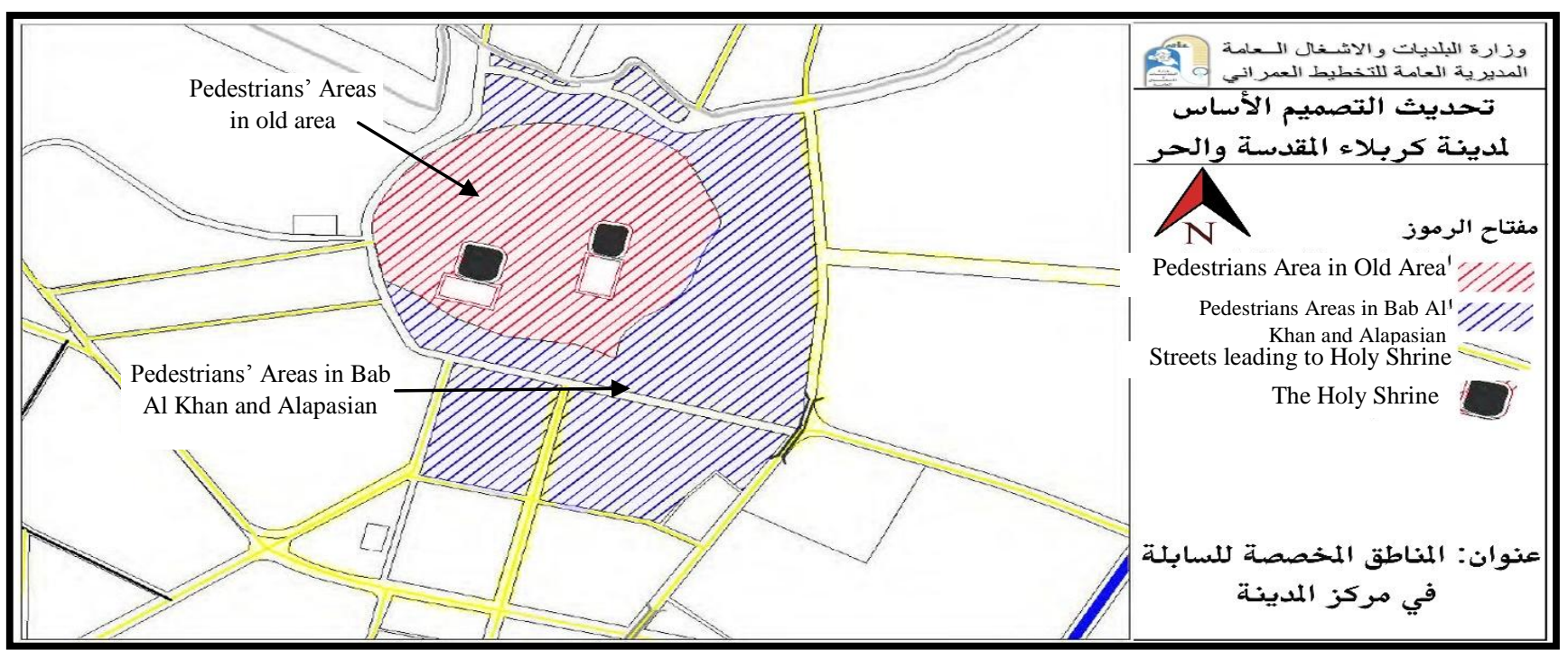

Source: Ministry of Municipalities and Public Works, General Directorate of Physical Planning (updated Master Plan for Karbala City and Al Hoor) to prepare the final report stage planned foundation, strategies, Iraq, 2009, p. 27-8

Proposed solutions to transportation plan for city center are:

1- Create Cities for Visitors: three entrances to head to Karbala city (Najaf, Hilla, Baghdad) to accommodate many visitors and provide them with all required services before they entered the city.
2- Street Use Existing Roads: for being broad and sufficient for this purpose, but if number of visitors you'll need a second floor of roads or running train him, which leaves visitors their vehicles in cities visitors attitudes and use buses to get to city center, of features of these buses are access to nearest of two area (Map 2).

Map (2) the streets leading from the cities of visitors to the citv center

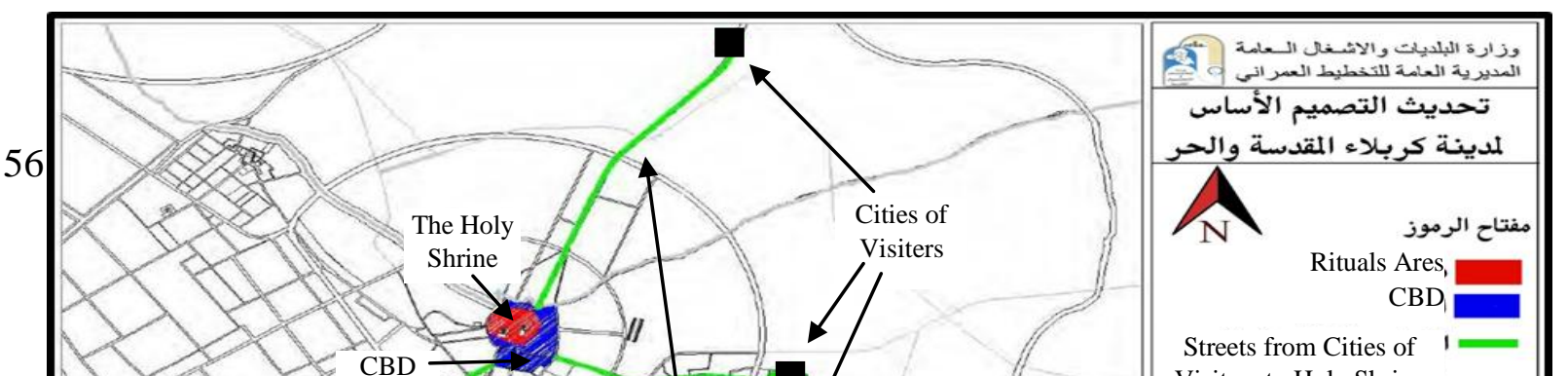


3- Use of Buses: In millions of visits used buses but would need to improve these tools as needed and may need to think about constructing a tram along the track.

4- Three Main Stations: Parking dedicated to Servino vicitore comino from ritiec huces Shoux/c

Map (3) Entrances and Paths Buses from the Cities of Visitors to the City Center

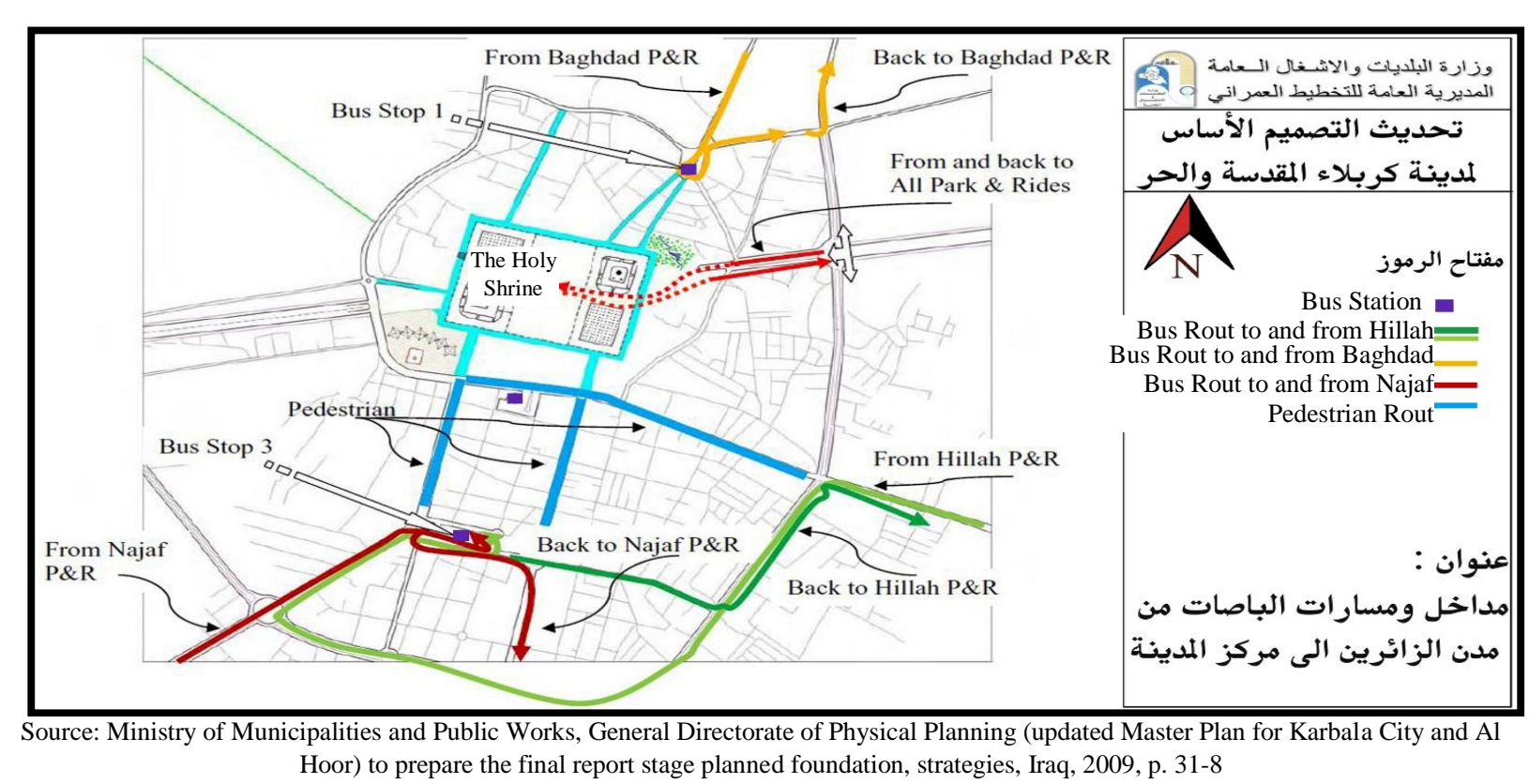

Source: Ministry of Municipalities and Public Works, General Directorate of Physical Planning (updated Master Plan for Karbala City and Al Hoor) to prepare the final report stage planned foundation, strategies, Iraq, 2009, p. 31-8
(Map 3) that stations used in normal days are stations 1 and 2, but in millions of visits will replaced station No. 2 Plant No. 3 for visitors and have use of station No. 2 is limited to municipal services.
5- Complete Separation Between Vehicles and Pedestrians Through the Work Bridge to Avoid it.

6- Ring Roads Around the City Center: there is a way around a dedicated pedestrian in the city center is used throughout year surrounds the city center is open for vehicles. In millions of visits it changes issue and become closed to pedestrian's areas, it is expanding pedestrians zone to include larger areas, and it changes the path of road and ring road is expanding (Map 4).

Map (4): Transportation Around the City Center

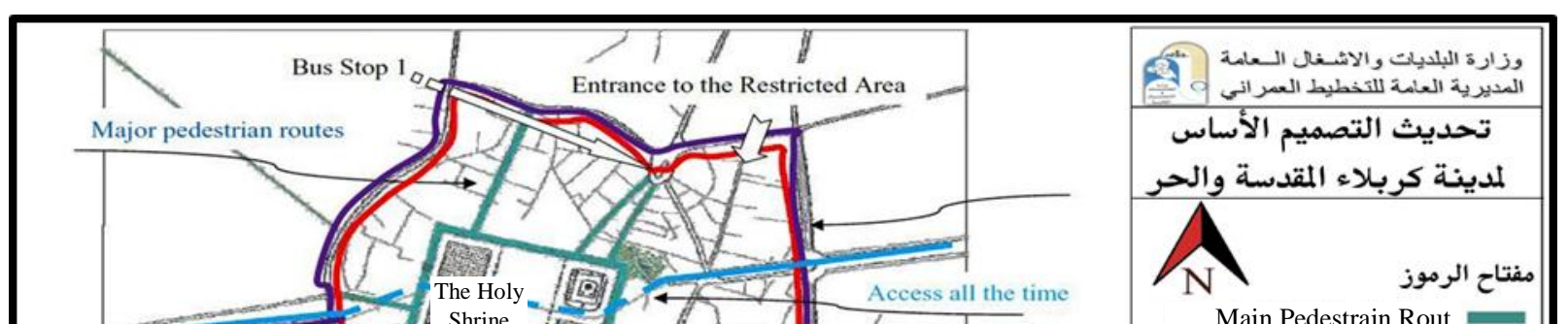


7- Entrances to the City Center: there is no problem in vehicles to enter the Alapasian area, but there is a problem in entry Bab Al Khan area and being located inside ring road around the city center, there are two entrances only possible to enter them (Map 5).
8- Procedures for Entering the City Center: Plan several measures for limiting entry of vehicles into the city center suggested, including: Charging for vehicle access into the city center each time you log in.

Map (5): Trends to Walk Around Vehicle and Parts Entering the City Center by the Internal Ring Road

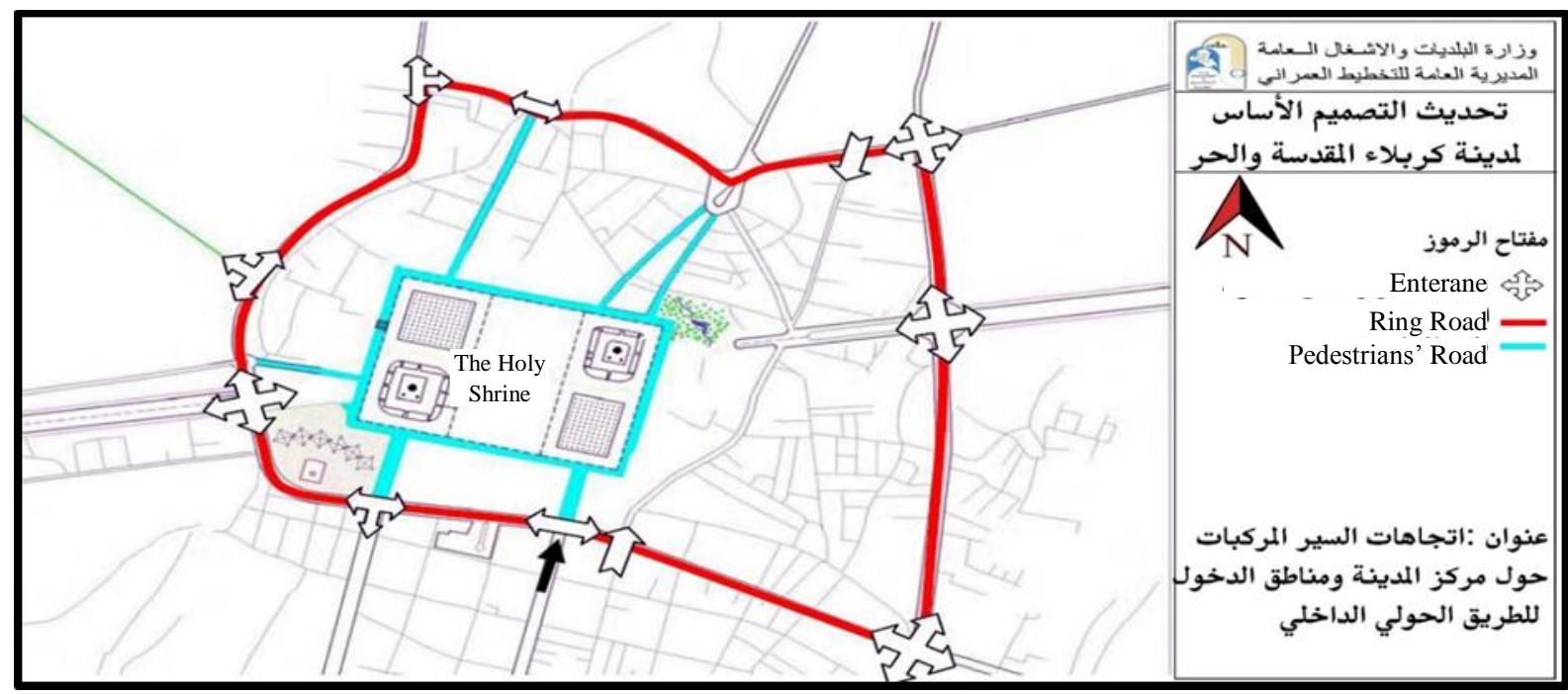

Source: Ministry of Municipalities and Public Works, General Directorate of Physical Planning (updated Master Plan for Karbala City and $\mathrm{Al} \mathrm{Hoor)} \mathrm{to} \mathrm{prepare} \mathrm{the} \mathrm{final} \mathrm{report} \mathrm{stage} \mathrm{planned} \mathrm{foundation,} \mathrm{strategies,} \mathrm{Iraq,} \mathrm{2009,} \mathrm{p.} \mathrm{20-8}$ 
Charging for vehicle access but otherwise traffic sign used in London city, where there are cameras monitoring vehicle access during day with a computer connected to a central.

- Access through granting of badges for section of vehicle.

- Determine number of times entry vehicle per day.

- Determine time allowed for vehicle to stay within city center.

- Adoption of more than one of procedures described above.

Choice of type defined above and authority to grant necessary approvals and determine fees or time period and like of all that has been said to be prerogative of provincial council exclusively.

9- Improve Traffic Situation: to take following actions:

- Use of technology and electronic means such as modern devices (Tags RFID), which sends electronic signals to computers for private sensors where number of vehicles entering and tended to.

- Place a large electronic screen at certain points or beginning of starting tracks Flags Visitors crowded areas and guiding them to optimal path that must be traveled by.

- Use of teams of young trainees well to guide visitors to roads are crowded wire as well as to places of service.

\section{The Proposed (2): Status of Public Transport in the City}

Transportation plan focused on public transport routes planning within neighborhoods. Plan relied on public transport network currently in place, a group of small buses serve neighborhoods or they work for a long time has been so reliable in charting new paths are more organized. The plan proposed the following:

- Introduction of body to move similar to interest of passenger transport in Baghdad to provide better services.

- Create a new path for each residential area newly arise.

- For Garages, public transport plan suggested that garages neighborhoods remain in same place but must be developed in a modern, and be unified garage this is an internal garage substitute for a garage Abn Hamza to serve the eastern regions and south east of city and creation of a new garage to north of city end Waeli Street serve new residential areas north of city. So, new path must introduce connects Najaf - Razzazah as well as course of last required linking north and south of city. When complete construction of new unified garage east of city must develop, a path linking it to all tracks and main bus stations in Karbala city.

A. Public Transport Pathways Within Planning

Districts: Tracks planning to draw tracks and bus garage public transport in coordination with residential areas, sites, and position adopted by current streets to get to best planning and suitable costs. The study has tracks through:

- Principles of Track selection: based on following:

- Planning tracks on principle of penetrating neighborhood tracks straight up to serve both sides of track with high population density.

- Distance traveled by people walking away from accommodation to passenger terminals.

- Characterized by flexibility in terms of design keep in mind that expansion in neighborhood in future.

- Path is capable of being expanded in coordination with surrounding buildings.

- Implementation of track should not affect functioning of vehicles and people's lives during implementation as well as it should when planning new neighborhoods that coincides with introduction of public transport routes so can be considered a part of movement in neighborhood.

- Track Selection Strategies: There are three different options are:

- Use of roads and streets of pre-existing public transport or private.

- Sometimes there are densely populated centers but is not linked to ways in some cases because of presence of natural inhibitors river or gardens and others and it must make their special ways of buses any public transport only to connect these areas with main route of buses.

- Can be bus paths with custom pedestrian's spaces.

Three options adopted in Karbala city plan, first option is used in neighborhoods because streets broad and does not affect existence of bus traffic. Second option is used in areas where drainage channel must work a short path through barriers to functioning buses. Third option is used in city 
center closed to pedestrians only and electric buses to serve the visitors.

- Buses Density, number and price of ticket: through work of buses on tracks for a long time and for years has been to identify tracks and number of buses on each track automatically according to amount of demand for it, including all Karbala city and Al Hoor. Plan relied on a series of theoretical studies to support work of buses on existing tracks through several theories to determine economic feasibility and quality of service, and these theories are:

- Link between cost of bus service to secure every citizen compared to number of buses per kilometer: made it clear that ideal point represents least possible number of buses or as much as possible number of passengers.

- Relationship between demand for and path length (distance between stations) show that greater demand must be less than distance between stations as well as the minimum length of time between bus and other.

- Relationship between price of ticket and number of buses: show that greater ticket price is less than number of trip, and by another if time period has increased between bus and other, this leads to lack of demand on bus also.

It concluded plan of all cases in above that if elected any of tracks, transportation costs are almost equal. Recommended a plan to train some specialists in field of transport on software program name (TRANUS), a study of its features tracks and analyze the costs and give appropriate solutions for each time period and can enter all possible cases to obtain accurate results.

\section{The Proposed (3) Status of Transport in the City}

Transportation plan focused on public transport routes planning within neighborhoods, existing streets and planned it, and squares.
A. Existing Streets in Karbala City: divide streets of Karbala city into three types: main streets or width $26 \mathrm{~m}$ above 16 Street, average street show in which $34 \mathrm{~m}$ and a total length of over $25 \mathrm{~km}$, and this task streets that have a direct impact in planning rest of city's species are small streets and do not have a direct effect or a clear planning. suggested to plan for year 2007 Created 4 streets just to north of city, either neighborhoods did not need new streets for being designed in the planning of 1990 and properly. Proposed new streets are:

- Inner Ring Road: currently $30 \mathrm{~m}$ and wooded on both sides and connects northern part of southern section of city and has squares in all intersections with sub streets so it is not considered a fast street is as much ease traffic momentum within city center, so it does not attract vehicle from abroad to him.

- Al Daawat Street: Is treed street starts from near Imam Hussein shrine and extends with $\mathrm{Al}$ Rashdeea River to reach Al Hoor shrine length of about $7.5 \mathrm{~km}$ and a width $200 \mathrm{~m}$ (100 from each side) This is a new route proposal begins west of city center of Albuebat area to Al Hoor shrine (map 6), main road width is $20 \mathrm{~m}$ people can in normal days, use of their cars to stand on either side of visits days shall be reserved for visitors and prevents use of private cars. This street was designed to serve as an outlet for people of city throughout year with establishment of gardens, parks and tourist facilities and Zoo. As well as to find a solution to problem of establishing processions and visitors in religious events, especially millions by providing housing in camps in neighboring orchards and modes of service.

- Alqami Road: Street is held in place Alqami River Historic, but in form of a tourist street.

- Road up north of city center to northern neighborhoods to be built.

Map (6): The Proposed Site for Al Daawat Street

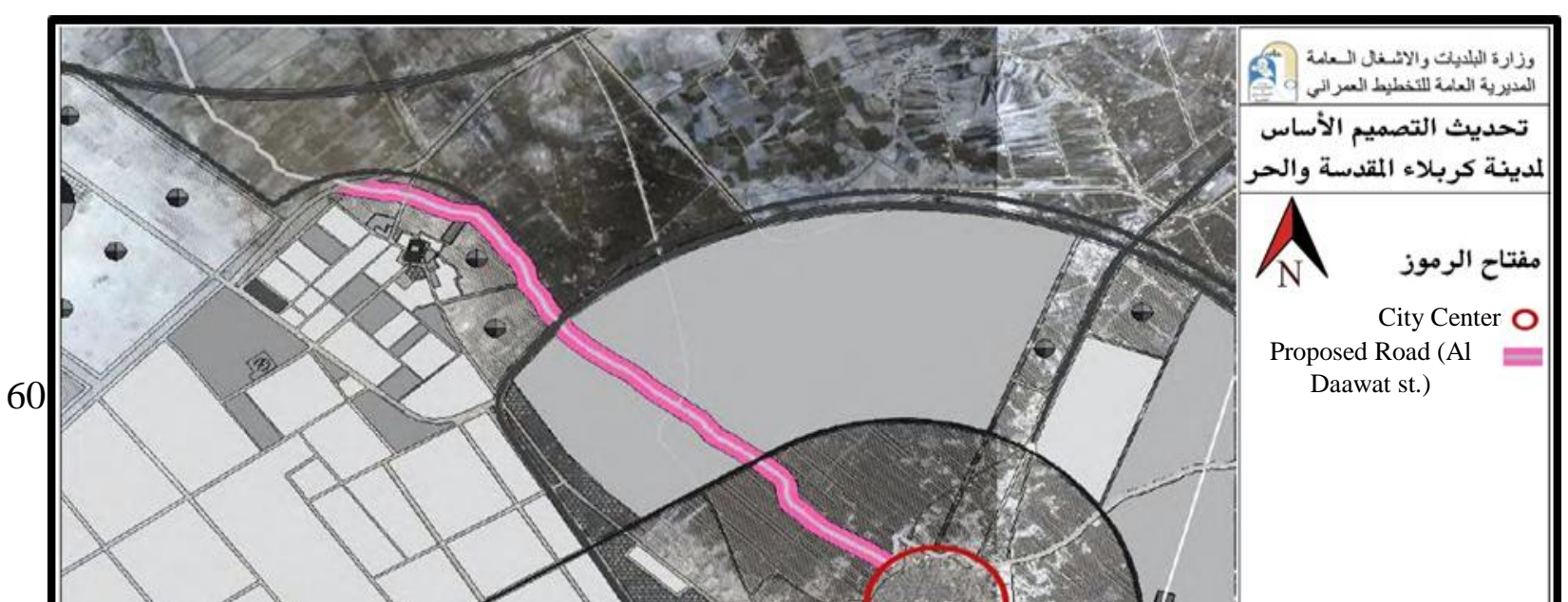


- Great Ring Road (outer): is way president, who will surround city. Which was designed by departments concerned were completed survey and design bridges located where business. This way became borders of new master plan for Karbala city, a key road and breather vital for city because it will develop transport network with neighboring cities without allowing large vehicles and trucks to enter city, as develop industries in Karbala at level of region without additional cost for establishment of private roads.

- Central Ring Road: have been added through new roads between outer and inner ring road called road passes mostly centrist middle of orchards on north-west and north-east, north and east. And intersects north with the road to Baghdad north of Al-Zahra neighborhood and intersects west, near children's entertainment on Al Hoor road, as well as with Al Daawat Street, either from east intersects in Fariha area with Hilla - Hindi road near Alkhader taller and extends up to road Najaf at end of current industrial district. This way relieves traffic momentum on inner ring road, especially millions of visits days because it is not far from city center, such as through outer ring road. Moreover, it serves mainly residential areas and new complexes proposed to northwestern part of it and south-eastern farming areas and orchards (north, west and east) of city.

- Ring Road for city center: This ring road radius of about $500 \mathrm{~m}$ wraps around city center. That most of its parts and a wide but there need to be a width of $30 \mathrm{~m}$.

- Expanding Al-Hussein Street to $100 \mathrm{~m}$ and removal of Karbala high school to continue the street to be linked to Zahra Street after Alzreba intersection to become an extension of street Najaf and central ring road.

B. Proposed New Squares: shows (Map 7) proposed new squares intersection inner ring road with other streets. Plan proposed update intersection of the Maitham al-Tamar Street between intersection of BabTouirij square leading to Al-Abbas Al-Ahli Hospital and is located opposite public garage serves next street along Aldokan street is characterized by a havey movement of traffic.

Map (7): Proposed New Squares

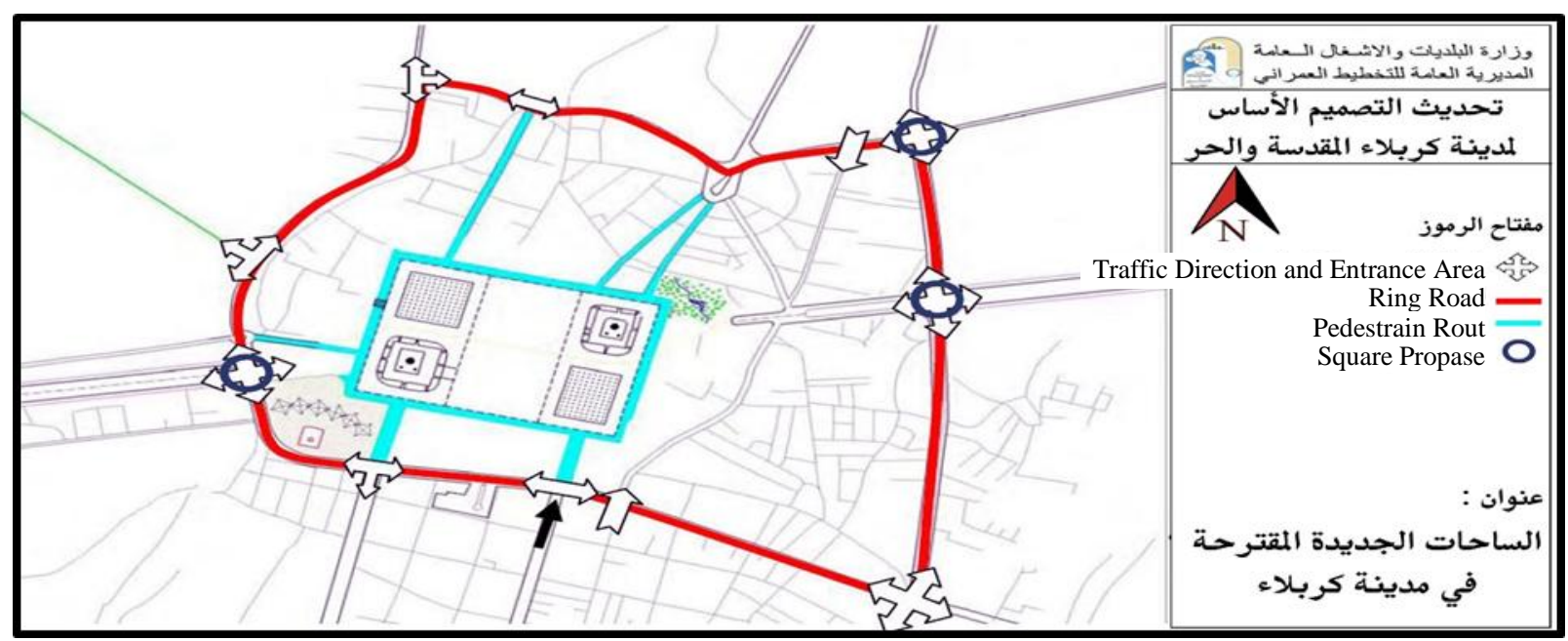


C. New Bridges: Ministry of Municipalities and Public Works constructing two main bridges in Bab Touirij and Alzreba intersection. But once completed traffic momentum will move to two junctions are important, as well as third intersection is as important as them. These three intersections are:

- First: intersection of Maitham al-Tamar Street and the street leading to Al-Abbas Al-Ahli Hospital for being served those who are going and coming to Touirij and province of Babylon, or southern provinces and Middle Euphrates cities.

- Second: end of cross-Abbas street with Najaf road, which is called Saif Saad intersection because it connects southern neighborhoods with city center and north.

- Third: stadium intersection at entrance of AlHussein neighborhood from Najaf street, through which it is located essential 5 streets (through Najaf street, Alaskan street, Hussein street, Altahdy Street, Altawan street and Albanaa Aljahiz street). Moreover, this intersection is a way middle ring road parts in new design, it is obvious that intersections of road annuals are bridges to ensure traffic.

\section{CONCLUSIONS}

1. The transport sector is the largest polluter of the city's environment and about $67 \%$ of the total pollution of the city.

2. Sustainable transport focuses on use of nonmotorized means of transportation primarily and therefore use of mass public transport, and has effect on:

- Reduce energy consumption by $2-2.5$ times use of automatic transport.

- Reduce gaseous emissions from automotive transport.

- Reduce land use allocated to transport sector at different rates depending on type of transport.
- Reduce cost of using car, it is costing 27 times more than using the bike and 134 times by walking.

- Reduce congestion and traffic accidents.

3. One of main reasons for implementation of sustainable transport in city is negative environmental impacts on city environment and increase of pollutants resulting from different means of transport with increase in number of private cars in world.

4. Sustainable transport aims to provide a sustainable urban environment that considers all segments of society to achieve social justice and traffic safety for the community, as well as reduce polluting emissions to environment, protect biodiversity and preserve the city's environment.

5. Mexico City experience focused on increasing public transport corridors (metro, bus, metro bus), implementing compulsory transportation program for pupils, increasing non-motorized transport by providing safe corridors, preventing cars in city center for one day per week and not driving on Saturday. Results of application of sustainable transport improve city environment, provide public transport, encourage non-motorized transport and reduce number of vehicles.

6. The proposals for sustainable transport plan for Karbala city indicate the following:

- Focus on walking in city center around holy shrines for security purposes and ability to accommodate visitors.

- Preparation of a plan of multiple ranges of mobility to accommodate numbers of visitors and it change according to season of visit and preparation of visitors.

- Adoption of electronic procedures to enter cars to city center when necessary, especially service cars.

- Use intelligent transportation to improve transport routes in the city. 
- Parts of the city have adopted a public transport plan at level of residential neighborhood to bring distances between residential areas and other activities in the city.

- Add some ring roads to avoid transit traffic in city and thus reduce pollutants emitted from them.

\section{Recommendations}

1. Need to transform traditional transport plans in Arab cities into sustainable transport plans to solve various transport problems, including pollution of city's environment.

2. Replace use of fossil fuels in operation of transport sector and use of biofuels, electric cars and environmentally friendly alternatives.

3. Reviewing urban land uses in city, especially use of transport and trying to reduce proportion and increase proportion of areas allocated for pedestrians and bicycles.

4. Reduce number of private cars for cities by setting laws and legislation that limit increase in numbers and encourage public transport and nonmotorized means of transportation.

5. Changing culture of mobility in Arab society towards encouraging sustainable transport through media, education, courses and others.

6. Review the transportation plan for Karbala city and make it more sustainable by

- Increased pedestrian areas include area of outer ring road permanently.

- Increase public transport within Karbala city.

- Construction of railways to transport visitors from other cities.

\section{REFRENCES}

1. Al Ameen, Fathi Hussein \& Zbilh, Awad Ibrahim (2015). Air Pollution and Environmental Risks Caused by Vehicle Exhaust in Misurata City. International Journal Court of Engineering Science and Information Technology, Vol. 2, No. 1.

$$
\begin{aligned}
& \text { الأمين، فتحي حسين \& زبلح، عوض إبراهيم (تلوث الهواء والمخاطر } \\
& \text { البيئة الناتجة عن عوادم المركبات في مدينة مصراته) البحلة }
\end{aligned}
$$

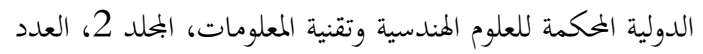

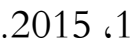

2. Amekudzi, Adjo \& Jeon, Christy Mihyeon (2005). Environment and Sustainable Development Program. Journal of Infrastructure Systems, Vol. 11, Issue 1, 31-50, ASCE.

3. Ashmawy, Saad Eddin (2008). Organization and Management of Transport: b\Bases, Problems and Solutions. fifth edition, Al Marekh Publishing, Riyadh, Saudi Arabia.

عشماوي، سعد الدين (تنظيم وإدارة النقل-الأسس المشكلات

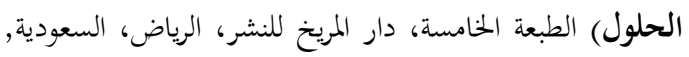

2008

4. Barakat, Ganeea (2010). Measuring Satisfaction of Public Urban Transport Users. Master Thesis, Faculty of Management Science, University of 8 May 1945, Algeria.

بركات، غنية (قياس رضا مستخدمي النقل العمومي الحضري

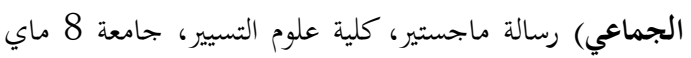

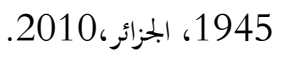

5. Bin Abdul Aziz, Halima (2011). Existing and Future of Sustainable Transport in Algeria. Master Thesis, Faculty of Economic and Business Sciences, Al Hadj Lakhdar-Batna University, Algeria.

بن عبد العزيز، حليمة (واقع ومستقبل النقل المستدام في الجزائر) رسالة ماجستير، كلية العلوم الاقتصادية والتجارية وعلوم التسيير،

$$
\text { جامعة الحاج لخضر -باتنة، الجزائر، }
$$

6. Dobranskyte - Niskota, A. \& Perujo, A. \& Pregl, M. (2007). Indicators to Assess Sustainability of Transport Activities, European Commission, Joint Research Centre, Institute for Environment and Sustainability.

7. IEA STATISTICS (2012). $\mathbf{C O}_{2}$ Emissions from Fuel Combustion Highlights. IEA STATISTICS, International energy agency.

8. Jeon, Christy Mihyeon \& Amekudzi, Adjo (2005). Addressing Sustainability in Transportation Systems: Definitions, Indicators, and Metrics. Journal of Infrastructure Systems, Vol. 11, Issue 1.

9. Litman, Todd (2013). Victoria Transport Policy Institute, Developing Indicators for Sustainable and Livable Transport Planning.

10.Local Government for Sustainability, ICLEI (2010). Mexico City's Green Plan: Eco Mobility in Motion. Case Study 120 Mexico City 2010 final.

11.Meyer, M.D. (2004). Transportation Performance Measures in Australia, Canada, Japan and New Zealand. Prepared for the USDOT International Technology Exchange Program.

12. Ministry of Municipalities and Public Works, General Directorate of Physical Planning (2009). Updated Master Plan for Karbala City and Al Hoor. to prepare the final report stage planned foundation, strategies, Iraq. 
13. Ministry of Municipalities and Public Works, General Directorate of Physical Planning (2009). Updated Master Plan for Karbala City and Al Hoor. Report of green areas in the foundation design for Karbala city, strategy 9.

14. Ministry of Planning, Central Bureau of Statistics (2010). Results and numbering of Population and Housing 2009.

15. Ministry of Planning, Central Bureau of Statistics, Directorate of Population Statistics and Labor Force (2014). Iraq's population estimates 2014.

16. Mqlata, Malik \& Bolibdh, Salih (2004). Permanent Transport and Maintenance Function. Master thesis, Urban Transport, Algeria, ENATT.

مقاتي مالك، بولبدة صالح (النقل الدائم ووظيفة الصيانة) مذكرة غاية الحزية

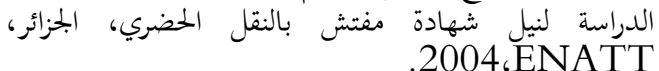

17. Qaded, Mahmoud Humaydan (2009). Urban Transport Planning. Arab Academy, Denmark.

قديد، محمود حميدان (تخطيط النقل الحضري) الاكاديمية العربية، الدنمارك، 2009

18. Qureshi, Intikhab Ahmed \& Huapu, LU (2007). Urban Transport and Sustainable Transport Strategies: A Case Study of Karachi, Pakistan. Tsinghua Science and Technology, vol. 12 , no. 3 .

19. Rajat Rastogi (2011). Promotion of NonMotorized Modes as a Sustainable
Transportation Option: Policy and Planning Issues. Current Science, Vol. 100, No.9. Special section: SUSTAINABLE TRANSPORT, Roorkee, India.

20.Rasheeda, Maaov \& Mohammed, Ceety (2015). Sustainable Urban Transport Planning. International Journal of Urban Planning and Sustainable Development, Vol. 2, No. 3.

رشيدة، معيوف \& الحمد، ستي (تخطيط النقل الحضري المستدام)

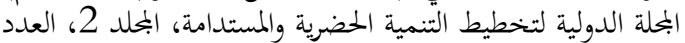
3 3، 3015.

21.Shanghai Manual - A Guide for Sustainable Urban Development in the 21st Century (2009). Environmentally Sustainable Transport for Asian Cities) UNCRD, Nagoya, chapter 4.

22. United Nations, Commission on Sustainable Development (2001). Transport and Sustainable Development Report. ninth session, Economic and Social Council.

23.Victoria Transport Policy Institute (2009). Transportation demand management) Training document, Federal Ministry of Economic Cooperation and Development ,April 2009. www.vtpi.org/tdm/tdm42.htm.

24.World Business Council for Sustainable Development (2004). Mobility 2030 Meeting the Challenges to Sustainability. The Sustainable Mobility Project, full report. 